\title{
ANTHROPOLOGY TODAY. A STUDY ON FAMILY WELLBEING AND TRANSCULTURAL INSIGHIS - A GERMAN JAPANESE STUDY
}

\author{
Christoph Wulf * \\ Freie Universität Berlin - Germany
}

\begin{abstract}
This article approaches the development of diverse anthropological movements just as well the relevance of the anthropological researches nowadays. It discusses the role of the cultural traditions in the development of the research areas that cross international cultural borders, as a central point in the anthropological research. The Anthropological transnational approach composes and powers the spirit of investigation in order to expand knowledge and enable the establishment of new investigation paradigms. This process is evidenced by results of studies on ethnographic case with German and Japanese families about family well-being, from an anthropological perspective.
\end{abstract}

Keywords: educational anthropology, emotions, gestures, rituals.

Resumo: O presente artigo aborda o desenvolvimento de diferentes correntes antropológicas bem como a importância das pesquisas em antropologia nos dias atuais. Discorre sobre o papel das tradições culturais no desenvolvimento de áreas de pesquisa que atravessam fronteiras culturais internacionais, como central na pesquisa antropológica. A abordagem transnacional de Antropologia estrutura e alimenta o espírito de investigação, de modo a expandir o conhecimento e, permitir a construção de novos paradigmas de investigação. Tal processo é evidenciado por resultados de estudo de caso etnográfico com famílias alemãs e japonesas sobre o bem-estar familiar, a partir de uma perspectiva antropológica.

Palavras-chave: antropologia educacional, emoções, gestos, rituais.

* Contact: chrwulf@zeda.fu-berlin.de

Horizontes Antropológicos, Porto Alegre, ano 23, n. 49, p. 21-59, set./dez. 2017 http://dx.doi.org/10.1590/S0104-71832017000300002 
The fragmentation and “deterritorialization” of contemporary anthropology hold considerable potential for the development of new modes of anthropological reflection and research. They also provide an opportunity to free ourselves from outdated traditions of our discipline and to redefine the horizons of anthropology. In this redefinition, the perspectives that are emerging from globalization are becoming increasingly important. Among other things, they have engendered criticism of the neoliberal economic trends that are marginalizing the social market economy and of the associated tendency for many societies to become more and more alike. Today, giving anthropology a global orientation means to open it up for research in all societies and cultures of the world and to address the issue of what will be the most important conditions of human life in the future.

Anthropology is a decentralized, polycentric discipline in which problems of representation, interpretation, the construction of deconstruction, and thus also methodological diversity are of central importance (Wulf, 2013a, 2013b). Two contradictory developmental trends clash with each other, one of and Exploring the Senses (Michaels; Wulf, 2014): Emotions (Baitello; Wulf, 2014; Frevert; Wulf, 2012), Performativity (Wulf; Göhlich; Zirfas, 2001; Wulf; Zirfas, 2007), and Ritual (Wulf, 2010), also revealed what, for example, Indian, Japanese, Arabic, and Western cultures have in common and what makes them different in these domains (Michaels; Wulf, 2012; Paragrana, 2011; Wulf, 2016; Wulf et al., 2011). The results of these studies show that in non-European cultures as well, historicity and culturality are central dimensions of anthropological knowledge. Through focusing on these dimensions, this research is making an important contribution to human beings' understanding of themselves in the twenty-first century (Wulf, 2017).

In what follows I present an outline of selected aspects of anthropology that cannot claim to be complete and will require further explanation and specification. Now that the abstract anthropological norm that centered mainly on the ideas, images, values, and norms of European-American culture has ceased to be binding, anthropology constitutes an attempt to conduct research on human phenomena in the conditions of a globalized world. As a result of this development, anthropological research is no longer fundamentally restricted to certain defined cultural areas or individual epochs. The aim of anthropological research is to contribute to a better understanding and better explanations of human phenomena and problems in our globalized world 
and thus also to a better understanding between people. The lively debates on the historical involvement of sections of anthropology in colonialism and racism, the problem of representation, and the extent to which the other can "speak back" are evidence of efforts to broaden the horizons of anthropology and open it up for new tasks.

There is a dual historicity and culturality in anthropology that arises from the historicity and culturality of the different perspectives of anthropological researchers and from the historical and cultural character of the contents and subjects of the research (Wulf; Kamper, 2002). The historicity and culturality of the anthropologists themselves form the background against which the phenomena and structures that came into being in a different time or culture are perceived and investigated. New research questions and methodologies develop in a reciprocal relationship as researchers reflect upon this dual historicity and culturality. In anthropological research it is important to think of historicity and culturality as belonging together and not, for instance, to play culturality off against historicity.

The approach to anthropology that I present here employs both diachronic and synchronic methods to investigate human societies and cultures. In addition to anthropological issues and the hermeneutic and text-critical methods from the historical sciences that are applied diachronically, field research with its numerous qualitative and quantitative methods still plays an important role as a method of synchronous anthropological research. The interpretative and reflexive methods, in particular, offer the possibility of lending expression to the individual and subjective perspectives (Wulf, 2013a, 2017).

Many anthropological research projects are inter- or transdisciplinary and multi- or transcultural. Because of their transdisciplinary nature, many studies transcend the limits of traditional disciplines and yield new insight by examining new research questions and objects of research, using new procedures and looking at things from new perspectives (Gil; Wulf, 2015; Wulf, 2016, 2017). The attempt to include multi- or transcultural aspects in anthropological research is also leading to the development of new research questions and perspectives that play important roles, particularly within the context of international anthropological research networks.

One new challenge that anthropologists have long failed to address is how to define the relationship between general insights and specific insights relating to human beings as individuals and human beings in general. While 
in archaeology, biological anthropology, and linguistic anthropology it is permissible to make universal statements about human beings and the human race, in historical and cultural anthropological approaches the emphasis is more on being able to use hermeneutic methods to make complex statements on particular historic cultural phenomena. These approaches are oriented toward the investigation and assurance of cultural diversity. However, even when we are concerned with cultural diversity, the question still arises as to what is common to all human beings. In these times of globalization, it is becoming increasingly important for anthropology to investigate the relationship between similarities and differences among human beings, cultures, and historical epochs. In this context the question as to the role of comparison in both diachronic and synchronic research in anthropology has taken on a significance that we urgently need to clarify. In my view, the aim of anthropological research is not to reduce but to increase the complexity of our knowledge about human beings. This requires interpretation, reflection, and self-criticism, and an ongoing, philosophically inspired critique of anthropology that must include an examination of the fundamental limits of human self-interpretation. In analogy to a definition of God in theology, there is thus talk of the homo absconditus (Wulf, 2013a, 2013b, 2017). This term expresses the notion that anthropological insights and findings can only grasp the human condition in part, that is, from various different perspectives and thus incompletely. Anthropological research and discovery is location-related and subject to historical and cultural change. Its starting point is a willingness to wonder or marvel that the world is as it is and not otherwise. Marveling (thaumazein) is the beginning of fascination with the mystery of the world and curiosity about the possibilities of anthropological knowledge.

Today's anthropology attempts to relate the historicity and culturality of its concepts, viewpoints, and methods to the historicity and culturality of what is under investigation. Anthropology examines the findings of the human sciences and develops a critique of itself based on historical and cultural philosophy, thereby paving the way for the investigation of new questions and issues. At the heart of these efforts lies a restlessness of mind that cannot be stilled. Research in anthropology is not limited to certain cultural contexts or single epochs. Reflections on the integral historicity and culturality of the research enable the discipline to leave behind the Eurocentricity of the human sciences and to focus on the unresolved problems of the present and the future. This 
aim implies skepticism toward all-encompassing and universal anthropological interpretations, such as those occasionally found in biological science, for example. Anthropology is not a single discipline. It touches on many different sciences and disciplines, including philosophy.

It cannot be regarded as a closed field of research. It is the result of the interplay between different sciences. Depending on the issue to be examined, the range of disciplines involved can be very different. The object and subject of anthropology can encompass the entire field of human culture in different historical areas and cultures. Anthropology presupposes a plurality of cultures and assumes that cultures are not closed systems; rather, they are dynamic, able to permeate each other, and they have an indeterminate future (Wulf, 2013a, 2017).

Anthropology can be understood as an academic attitude toward examining issues relating to different times and cultures. This is why anthropological research can be found in many different disciplines, such as history, literature, linguistics, sociology, psychology, and the theory of education (Wulf; Zirfas, 2014). However, the research frequently tends to transcend the boundaries of individual disciplines, thereby becoming transdisciplinary. This results in completely new scientific disciplines and issues that require new forms of scientific interaction and cooperation. Many different research methods are used in these processes. Historical-hermeneutical processes of text, image and music interpretation, qualitative social research methodologies, and philosophical reasoning are widely used, the latter being an approach that is difficult to categorize in terms of specific methodology. Some research makes use of artistic and literary materials, thereby transcending the traditional boundaries between science, literature, and art. A growing consciousness of the role of cultural traditions in the development of different research areas, subjects, and viewpoints has made the increasing trend toward crossing international cultural boundaries a central issue of anthropological research. In the light of globalization, this transnational approach to anthropology is becoming increasingly important. It provides the framework that nurtures a spirit of inquiry and a commitment to expanding our knowledge, which in turn lead to the development and testing of new research paradigms.

The demise of a binding anthropological norm has made it necessary to take a fresh look at the most important anthropological paradigms and try to locate their common ground as well as their differences. This has also given 
rise to a need to define the tasks and procedures of anthropology and to illustrate their importance for research in the humanities as well as the social and cultural sciences (Wulf, 2013a, 2017).

\section{Anthropological paradigms}

If we wish to put the epistemology of anthropology on a more profoundly reflected footing, then a confrontation, at once critical and constructive, with the anthropological paradigms which are internationally significant is absolutely indispensable. Speaking about anthropology in the humanities and social sciences, we are thus referring to:

- Anthropology of evolution and hominization

- philosophical anthropology developed in Germany

- historical anthropology and the history of mentalities, initiated by historians in France and taking its cue from the Annales-School

- the American tradition of cultural anthropology and

- historical cultural anthropology.

In order to provide a framework for anthropology I suggest that we use the paradigm of historical cultural anthropology as a basis for further research. This paradigm integrates perspectives from the other four major anthropological paradigms and provides a basis for an adequate understanding of social phenomena, processes and institutions in a globalized world. I shall focus on diachronic and synchronic perspectives and historical and cultural research within anthropology. Due to the limitations of space I have selected just one of the major research projects in the field of historical cultural anthropology in Germany to present to you. This project serves as an example of ethnographic research. Together with historical and philosophical methods, the ethnographic approach is one of the main methods of anthropology, conceived as historical and cultural anthropology (Wulf, 2002, 2017).

\section{Anthropology of evolution and hominization}

As the branch of anthropology devoting itself to the study of hominization stems from an attempt to fit the natural history of human beings into the

Horizontes Antropológicos, Porto Alegre, ano 23, n. 49, p. 21-59, set./dez. 2017 
horizon of anthropology in order to understand the "lost paradigm" which the human is (Morin, 1973; Morin; Wulf, 2003). On the other hand, the natural history of human's evolution can only be understood when considered as part of history. Its irreversibility, as well as that of the history of life itself, is grasped today as a consequence of material self-organization, which also represents a facet of reflexive historical cultural anthropology. Just like anthropology stresses the historical character of the way it frames its problems and of its analyses, the theory of evolution insists on the radical chronologization of nature and of the natural history of the evolution of human beings. Time and history are thus central dimensions of evolution. Hominization is the long process of evolution, from Australopithecus to primitive man, from Homo erectus to the modern representatives of our species, which unfolds as a multi-faceted morphogenesis arising from the combined effects of ecological, genetic, cerebral, social and cultural factors.

Hominization can be understood as a multi-dimensional morphogenesis arising from the interplay between ecological, genetic, cerebral, social and cultural factors. Current understanding is that this process necessitated three types of change. The first were ecological changes which led to the expansion of the savannah and thus to an "open" biotope. Second, a genetic change took place in the highly developed primates which were already walking upright. Third, there was a change in social self-reproduction due to the splitting off of young groups and the use of new territories. The new biotopes led to significant increases in the requirements for dexterity and communication skills for the two-handed bipedal life-forms which were already able to use and manufacture simple tools. These hominids who had become omnivores, had to develop new levels of alertness, watchfulness and cunning to cope with the demands of hunting. They needed new forms of co-operation and social responsibility to protect themselves against predators, search for food, hunt and divide their prey and rear their young. This led to a further development in cerebral capabilities. It was therefore the new ecosystem - the savannah -, which triggered the dialectic between the feet, hands and brain and which became the source of technology and all other human developments. As these processes unfolded, a paleosociety developed with a culture-based division of work between men and women and the development of hierarchical social relations. Language and culture became gradually more complex. The process of hominization was intensified by a prolonged youth or neoteny, incomplete 
development of the brain at birth and prolonged childhood with longer affective ties between the generations, with the associated potentials for comprehensive cultural learning. The cerebralization, prolonged youth and increased social and cultural complexity were mutually dependent. The complexity of the brain requires a corresponding socio-cultural complexity. The creative potential of the brain can only be expressed and develop in a socio-cultural environment that grows in parallel. This dialectic relationship means that humans have been cultural beings from the very beginning, i.e. their "natural" development is cultural. The final stage of this process of hominization is, in fact, also a beginning. The human species, which has reached its completion in Homo sapiens, is a youthful and childlike species, our brilliant brains would be feeble organs without the apparatus of culture, all our capabilities need to be bottle-fed. Hominization was completed with the irreversible and fundamental creative incompleteness of human beings. The course of hominization clearly illustrates that Homo sapiens and Homo demens are inseparably linked and the great achievements of humankind have their downside: the horrors and atrocities perpetrated by the human race.

\section{Philosophical anthropology}

While taking evolution into account in anthropology serves to highlight the shared lineage and mutual parentage of all forms of life and the long timespan of hominization as well as the general laws of evolution, philosophical anthropology turns its attention to the particularity of "man's" character.

The centerpieces of philosophical anthropology are the anthropological works of Max Scheler, Helmuth Plessner and Arnold Gehlen. Despite considerable differences between these authors, their works of the first half of the twentieth century are referred to collectively as philosophical anthropology. Their common purpose was to establish how human beings differ from animals, what the specific conditions of being human are and to define the human condition. Despite their differences, all three authors were in agreement that the central focus of anthropology is the human body which is in itself the starting point for differentiating between humans and animals. In a time when humans had come to have grave doubts about themselves and were aware of this, it was hoped that by focusing on the body, knowledge gleaned from natural sciences could serve as a starting point for a revalidation of human

Horizontes Antropológicos, Porto Alegre, ano 23, n. 49, p. 21-59, set./dez. 2017 
nature. This orientation was associated with a rejection of idealism and the philosophy of consciousness. Philosophy was no longer interested in reason, but in the creative diversity of life.

In 1927, Max Scheler gave a lecture in Darmstadt entitled Die Sonderstellung des Menschen ("Man's Particular Place"), which was published in 1928 under the title Die Stellung des Menschen im Kosmos (Man's Place in Nature) and is regarded as the beginning of philosophical anthropology. When Scheler died in the same year he left no concrete preparatory material for the anthropological work he had intended to publish in 1929. The philosopher and biologist Helmuth Plessner, however, published his main anthropological work Die Stufen des Organischen und der Mensch (Levels of Organic Being and Man) in 1928. Despite large differences in material and argument, Scheler's article and Plessner's book share the assumption that organic life is structured in levels. Arnold Gehlen's work Der Mensch, seine Natur und seine Stellung in der Welt (Man: His Nature and Place in the World) took a different approach and focuses on humans as acting beings.

The preoccupation of this strand of anthropological thought was to understand the essence, the nature of human beings in general. Within this framework, anthropology concentrated upon a comparison between "man" and animal (Gehlen, 1988; Plessner, 1970), with a view to distinguishing shared features and differences. To grasp the conditio humana philosophical reflections were brought to bear upon biological insights. It was thought that the conditions for the formation of the human species could be glimpsed in such biological and above all morphological characteristics. This perspective has had two consequences. On the one hand, the focus of anthropological reflection and research has from then on shifted onto the human body. On the other hand, the development of a generalizing discourse relating to one unique and unitary model of man could be observed. While the latter seems appropriate for attributing typical characteristics to a species, such as walking upright, it ceases to make sense once this narrow focalization is relinquished and anthropology is stretched to accommodate the historical and cultural reality of human's existence.

Due to its focus on the human being as such, philosophical anthropology fails to address the historical and cultural diversity of human beings in the plural. This is the inevitable consequence of the interesting attempt to develop a single coherent concept of "man”, which failed to capture the diversity of 
human life and could hardly have achieved its ambitious goals. To investigate this is the aim of a branch of historical science that is oriented towards anthropological issues.

\section{The Annales School and the History of Mentalities}

Anthropology underwent an additional development and refinement in a historical turn, which can be discerned in the historical treatments of anthropological topics of the Annales School and the history of mentalities which flowed from it (Ariès; Duby, 1985; Burke, 1991). Historiographically, this alignment with anthropological themes and topics represents a novel orientation. It completes the representation and analysis of the dynamic of historical events and of socio-economic conditions effected by structural and social history. From concentrating on anthropological themes and topics, inquiries turned increasingly to interrogating actual social structures as well as the subjective elements of the social individual's actions. In this vein, elementary types of human behavior and basic situations are analyzed. Quite opposed to those hypotheses which insist that these basic situations be rooted in a character common to all human beings, the practitioners of historical studies with an anthropological orientation inquire into the specifically historical and cultural character of each of these phenomena. Fernand Braudel's study of the Mediterranean (Braudel, 1949), Emmanuel Le Roy Ladurie's on the village of Montaillou (Ladurie, 1978), Carlo Ginzburg's on the world of millers around 1600 (Ginzburg, 1982) may be cited as successful examples for this endeavor. The research into fundamental human experiences or into the history of mentalities, which has been undertaken in connection with this historical turn, is inevitably less rich in detail. Often, this is due to the limits which the insufficiency of sources imposes upon the possibilities of historical knowledge, which is born of the tension between event and account, reality and fiction, structural history and narrative historiography (Le Goff, 1990). A precise delimitation of narrative and description is impossible: historiography represents both controlled fiction and controlled construction.

Historical anthropology investigates elementary situations and basic experiences of being human. It studies a basic stock of patterns of thought, feeling and behavior that is anthropologically constant (Dinzelbacher, 1993), basic human phenomena and elementary human behavior, experiences and 
basic situations (Medick; Sabean, 1984). Although it could be understood otherwise, these classifications are not concerned with making statements about humans in general but with gaining an understanding of the multi-dimensional conditions of life and experiences of real people in their respective historical contexts. These anthropological studies are oriented towards investigating the multitude of ways in which the different ways of human life are expressed and presented. This diversity of phenomena is paralleled by the multi-dimensionality and open-endedness of anthropological definitions and research paradigms. In this research it is necessary to develop a feeling for the difference between the historical world under investigation and the current frame of reference of the research. Since, for example, linguistic metaphors and terms have different meanings in different times and in different contexts, these differences in meaning must be taken into account. The same applies with regard to research into basic human behaviors, experiences and fundamental situations. From the point of view of the historical sciences, the feelings, actions and events under investigation can only be understood in terms of their historic uniqueness. It is this that lends them their dynamic nature and makes them subject to historical change.

\section{Cultural Anthropology or Ethnology}

Even though anthropology is the result of a process of philosophical and scientific evolution, it can no longer pretend, these days, that at the end of the day only Europeans exist as human beings and act as though these putative European humans were the only possible yardstick. It is obvious, even in an era of globalization deeply marked in its content and form by Western culture, that different forms of human life exist today, influenced by various local, regional and national cultures. The Anglo-American tradition of cultural and social anthropology has turned its attention to this situation. Within this framework, the accent lies on the social and cultural diversity of human life. Its research explains both to what extent cultural evolutions are heterogeneous and to what extent the profound diversity of human life remains disregarded. It is precisely the analysis of foreign cultures which makes it plain to us how limited and troublesome this understanding is. Comparing human expressions and manifestations across several cultures has demonstrated to what great extent the study of cultural phenomena brings forth new uncertainties and questions. 
Thanks to the analysis of cultural manifestations drawn from heterogeneous cultures, anthropological inquiries make an important contribution to the elaboration and development of anthropology; while its ethnographical methods oblige practitioners to draw upon historical sources. Quite apart from creating a sensitivity for the strange and foreign character of other cultures, it also creates a sensitivity for that which is strange and foreign in its own culture. The (self-)reflexive point of view adopted by cultural anthropology towards European cultures has contributed to a considerable evolution and advance of anthropological knowledge (see Evans-Pritchard, 1981; Harris, 2001; LéviStrauss, 1992, 1999; Malinowski, 1992; Mead, 1980, 2001; Sahlins, 1976).

\section{Historical Cultural Anthropology}

Being confronted with philosophical reflection has given rise to a critique of anthropology which is constitutive for anthropology in the field of the humanities, and which focuses on the objects, themes and methods of research-based knowledge acquisition. The specific situation of human beings in the world, the comparison with animals or machines, is no longer anthropology's center of interest. Instead, manifold historical and cultural inquiries focus on studying and understanding the cultural diversity of social life. A particular and very pronounced interest in the study of current phenomena is noticeable. In my understanding, the research undertaken by historical anthropology is no longer the exclusive preserve of the historian, as was still the case within the framework of the Annales School. In the continuity of this broader conception, historical cultural anthropology means an orientation towards the humanities and the social sciences. It touches upon the historical and cultural determination of culture and its manifestations, and demands that their study and reflection take into account ethnological and philosophical perspectives and questions. Committed to this task, historical cultural anthropology makes an important contribution to the self-comprehension and self-interpretation of cultures and societies today. In this process of cultural understanding, research efforts rapidly run the risk of being unable to move beyond the level of their own initial insights. To safeguard against this risk, historical cultural anthropology needs to reflect upon its relation to power and knowledge, as well as to make efforts specifically aimed at bringing to light the involuntary and often unacknowledged normative implications of its own research. The

Horizontes Antropológicos, Porto Alegre, ano 23, n. 49, p. 21-59, set./dez. 2017 
critique of anthropology is itself a constituent part of historical anthropology, which leads to an epistemological insecurity and once more casts doubt upon the concordance between the name of "man" and the names of the essence, of logic and of the concept of identification, of the reach of hermeneutics, of history (understood as the history of progress and acquisition), and of the subject itself (in so far as it is conceived as the one and only central field of conscience and constitutive in its rapport with the world).

Within this frame of reference, reflexive historical cultural anthropology designates the multiform trans-disciplinary and trans-national efforts to follow up on the universal idea of an abstract anthropological norm and to continue analyzing other human phenomena. Historical cultural anthropology is the common denominator of history and the humanities. Nevertheless, it does not exhaust itself either in a history of anthropology as a discipline nor in making a contribution to history from the perspective of an anthropological subdiscipline. It attempts, rather, to bring into an accord the historical and cultural determination of its perspectives and methods with the historical and cultural determination of its object of study. As a consequence, historical cultural anthropology can harness insights gleaned in the humanities with those yielded by a critique of anthropology based on the history of philosophy, and bring both to fruition in order to create new perspectives and lines of inquiry out of a new consciousness for methodological problems. At the heart of these efforts, an inimitable and voracious agitation of thought and research holds sway. Historical anthropology is limited neither to certain spatial frames nor to particular epochs. Reflecting on its own historicity and its own cultural condition, it succeeds both in leaving behind the eurocentrism of the humanities and the interest in history (antiquarian in the final analysis) as well as in giving precedence to current and future problems (Wulf, 2002, 2010, 2017; Wulf; Kamper, 2002). In the second part of this article I will present the findings of a German Japanese ethnographic study on family wellbeing with some transcultural findings which demonstrate the attempt to combine particular ethnographic findings with the perspective on what we as human beings have in common.

\section{A study on family wellbeing and transcultural insights}

Leading a happy life is the object of all people. How is wellbeing and happiness to be understood? How are family and wellbeing interrelated? How

Horizontes Antropológicos, Porto Alegre, ano 23, n. 49, p. 21-59, set./dez. 2017 
do people lead a happy life and what contribution does the family make to this? The number of self-help books, newspaper articles, television programs, and Internet platforms in which answers to these questions are sought has become enormous. What role the family plays for well-being and happiness is at the focus of the following considerations.

I did not investigate what happiness is, but instead ask more cautiously how families stage their wellbeing and happiness, how they perform it, how they create it. What a fulfilled life looks like and how it is brought about are among the central questions of religion and philosophy, sociology, psychology, pedagogy, and anthropology. The answers differ from each other, contradict each other in part, and are often so complex that they cannot be comprehended without the historical and cultural context in which they were given. The objective of this study is to describe and analyze in six case studies how families create their well-being and happiness. In accordance with a long cultural-anthropological tradition, I am also studying a family ritual that serves as a window into our own culture and the foreign culture (Baumann; Hauri, 2008; Morgenthaler; Hauri 2010).

With three German-Japanese research teams, I was studying the celebration of Christmas in three German families and the New Year's celebration in three Japanese families. In the process, I wanted to find out the forms in which these families celebrate their important family celebration in order that their members are satisfied and happy. I was interested in the question regarding which similarities and which differences can be identified in such culturally diverse families using mixed research teams. With participatory and videosupported observation, with interviews and group discussions, with photos and videos, and with historical and cultural analyses, I work out the various stagings and performances of family rituals and show how their performative character contributes to the creation of family happiness on these holidays. It wasn't easy to find six families who were willing to grant an international research team access to their intimate family celebration while taking into account the criteria of theoretical sampling (Glaser; Strauss, 1998) during the selection. These families belong to the milieu of the middle class, within which the selected families comprise a broad spectrum. In my culturally mixed teams, a methodologically interesting overlap between a variety of cultural perspectives occurred in regard to the perception and interpretation of family rituals. This led to a new form of communicative validation, which presented 
me with a great number of methodological problems due to the complexity of the study and its associated open questions (Kraus et al., 2017).

With the study of happiness in heterogeneous families, this ethnographic study also makes a contribution to the biographical study of emotions. Through the research into two very different cultures, I investigated a broad spectrum of cultural differences, within which the diversity of the ritual creation of family happiness becomes very clear. With a consciousness of these differences that extend down to the deep structures of the family and their members, several transcultural elements which contribute to the creation of family wellbeing and happiness can be identified and are later described.

\section{Happiness as the meaning of life: historical perspectives}

The great differences in the way that happiness is understood is shown by the variety of terms that have arisen in the European cultures and in Japan, terms whose semantic and contextual reconstruction requires their own analysis not to carried out here. The terms contribute to making the diversity of relevant aspects visible. In Middle High German, gelücke means the positive outcome of an action or occurrence. To this day, the term fortuna and its related expressions in the romance languages continues to denote a side of happiness which "falls onto" people and for which they are not responsible. In contrast to this, beatitudo denotes the state of being happy, something to which people can definitely contribute. This side is also emphasized when it is said that "man is the architect of his own fortune," for example - that is, each person bears responsibility for his or her own happiness. The corresponding differentiation can already be found in the Greek between eutychia, the happiness that is "given" to people, and eudaimonia, the state of being happy, to the creation of which the individual can contribute. This differentiation can also be found in other European languages. For example, in English one speaks of luck and happiness, while French has the words chance and bonheur. The U.S. Constitution expressly mentions the pursuit of happiness as a human right (Lauster, 2004).

For Socrates, the happy life, the eudaimonia, consists of a reason-based life that is virtuously led, within the framework of which it is better to suffer injustice than to do injustice. For Plato, a happy life is made possible by the individual looking at the ideas and being able to bring about the good and the 
beautiful, the kalokagathia as the unity of the good, the beautiful, and the just. Aristotle later develops a stage model of happiness in which bliss is placed on a higher level than the other human ambitions such as honor, desire, and reason. For the Epicureans, it is ataraxia, emotional tranquility, and for the Stoics apatheia, lack of passion, that are the decisive conditions of a happy life (Horn, 1998; Hoyer, 2007). Seneca formulates the possibilities of a happy life as follows: "Those who have insight are temperate; those who are temperate are also calm; those who are calm cannot be ruffled; those who cannot be ruffled have no worries; those who have no worries are happy: thus the insightful person is happy, and insight is sufficient for a happy life!” (Seneca, 2007, Epistulae morales 85, 2).

\section{Structural elements of happiness}

In Japan and Germany, there are different notions of happiness. These are also associated with differences in the social and cultural practices for bringing forth happiness. These practices are an important part of the intangible cultural heritage. They and the emotions and conceptions associated with them play a considerable role in the development, preservation, and change of cultural identity. These practices with which families create their family happiness also contribute to bringing forth a cultural identity that differs in Japan and Germany. Here, cultural identity designates a conjunction of characteristics that can be used to differentiate individuals and groups from others. Within these characteristics, the broad spectrum of symbolizations and practices plays an important role.

In view of the tendency toward homogenization and uniformization of the world due to globalization, the significance of diversity received ever greater emphasis over the last decade, with the objective of preservation and promotion of cultural identity. This development finds clear expression in the UNESCO Convention for the Safeguarding of the Intangible Cultural Heritage from 2003 and in the UNESCO Convention on the Protection and Promotion of the Diversity of Cultural Expression from 2005 (UNESCO, 2003, 2005). In the face of the tendency toward standardization, both conventions underscore the necessity of cultural difference and identity (Wulf, 2005b; 2006). Rituals are among the most important forms of intangible cultural heritage. Among them, day-to-day and celebratory rituals play a central role. They contribute 
to creating a feeling of community and coherence, thus generating familial well-being and happiness. In this way they have an important influence on the cultural identity of family members. This becomes clear in our study of familial celebratory rituals on Christmas in Germany and for the New Year's celebration in Japan. It can be shown here how familial rituals contribute to the development of a social and cultural identity of family members. In the staging of German and Japanese family rituals, it becomes clear how similar and at the same time different the practices are for bringing forth well-being and happiness of the family. With the intention of providing examples, five structural elements are described here that play a central role in the design of the rituals belonging to the intangible cultural heritage, the generation of emotions of happiness, and the development of cultural identity.

\section{Language and imagination}

Recent research on emotions has made it clear how important it is from a cultural studies perspective not to ontologize emotions of happiness. Emotions are not isolatable substances, but rather always linked with other characteristics of the individual. In many cases, it is language that contributes to the ability of emotions of happiness to arise and be felt. An example of this is the rhetoric of romantic love. Without it, these notions of love and the expectations of happiness associated with them would not have been able to develop. If a culture has a term with which a certain aspect of happiness is denoted, it is probable that forms of expression for this emotion can also be found in this culture. If this word is missing in another culture, it is probably also difficult to identify the aspect of happiness referred to with this word. The Japanese word amae is an example of this. If you were to try to describe the aspect of love and happiness referred to with this word, you might say: "to depend on the love of another" or "to put oneself at the mercy of the sweetness of another.” In the Indo-Germanic languages and in the European imagination, there is no designation for this aspect of love and happiness. This word that cannot be translated into German is nevertheless of central importance for understanding the Japanese mentality. The question is now the extent to which the emotion of happiness and love referred to with this word can be understood by people from other cultures. Several answers are possible here. One position proceeds on the assumption that this emotion can also be understood 
by people from other cultures with the aid of linguistic descriptions. Another position points out that this only possible to a very unsatisfactory extent, and that what is needed is not just linguistic knowledge, but also the incorporated ideas, emotional relationships, and performative actions referred to with this word. While the first position places more emphasis on the similarity in the emotional endowment of people, the second position refers to cultural differences that can hardly be overcome.

\section{The flowing of emotions}

Many emotions of happiness arise in interactions with other people, in ritual communication between them, and in mimetic self-reference. They can be described as fluid. Such a characterization implies that emotions of happiness change in the practices of everyday life. They overlap with previous emotional experiences and form ensembles of emotions. In this process, emotional dispositions are selected and updated. A special characteristic of human emotionality consists of the fact that they are influenced by moods that persist over a long period of time. These moods have an influence on how emotions are "toned." "The world of the happy is quite different from that of the unhappy" (Wittgenstein). Emotions determine our relationships to other people and to the world that surrounds us. They are evaluative, that is, they evaluate the events that happen to us and allow us to act in accordance with this evaluation. This emotional evaluation of actions of other people often takes place unconsciously or semiconsciously and is only accessible to the conscious mind in a limited manner. This evaluative side of emotions supports us in orienting ourselves in the world and with respect to other people. It helps us make distinctions and grasp the meaning of social situations, actions, and contexts. Their energetic side enables individuals and communities to shape sense, meaning, and identity (Greco; Stenner 2008; Hahn, 2010a, 2010b; Harding; Pribram, 2009; Le Breton, 1998; Paragrana, 2010a, 2010b; Wulf, 2010, 2011; Wulf; Kamper, 2002; Wulff, 2007).

\section{Physicality and performativity}

If you accentuate the performative character of the creation of happiness, there is a shift in the focus of attention. Interest is directed to a lesser extent 
toward understanding how notions of happiness are to be understood and interpreted and more toward grasping how people express, represent, modify, and control the various feelings of happiness. In this case it is essential to study the process in which being happy is staged and performed. The forms of physical expression of emotions are thus placed at the center of attention (Ekman; Sorenson; Ellsworth, 1982). Physicality, habitualization, and dramaturgy of emotions become important. In this context, rituals and gestures are of major importance (Wulf; Fischer-Lichte, 2010; Wulf; Zirfas, 2004, 2007). This change of perspective is associated with developments that have led to the designation of modern societies as staging societies in which people's living space becomes a "small theater" where they continuously put on display and market themselves and their role in the community.

\section{Mimetic processes}

Happy people often make other people happy as well. One reason for this is in the mimetic processes in which people become more similar to each other. As in the case with laughter, emotions of happiness also involve a sensuous transfer in which our body is infected with the joy and happiness of other people. Without us becoming aware of it, we assimilate bodily movements and mimetic forms of expression. We become a sounding box of the emotions of happiness of other people. Their happiness affects us, and our affects strengthen their emotions. An assimilation to the emotions of happiness of other people causes us to be able become happy ourselves, namely in a way that we are not happy like the others, but instead happy in our own way. We reflect the happiness of other people back at them and intensify their emotions. We discern the performative concretization of happiness and learn the practices with which we stage, perform, and pass it on to subsequent generations (Gebauer; Wulf, 1995, 1998, 2004; Paragrana, 2010a; Suzuki; Wulf, 2007; Wulf, 2005a).

\section{Rituals}

In all human societies, rituals contribute to the intensification, steering, and control of emotions (Michaels, 2007; Michaels; Wulf, 2011; Wulf; Zirfas, 2004). They lead the involved persons to relate to each other. They are of 
central importance for the creation of familial happiness. Their performativity creates social forms of happiness. In this process, the movements of the body play an important role. In common action, they create social emotions of proximity, affection, and trust. The dynamics of familial rituals ensure that a ritual action is not a mere copy of a previous action. Rituals are similar to each other, to be sure, but they also create new practices with reference to that which has preceded them. If this is not the case, they lose their vitality and degenerate into stereotypes. Rituals are social practices in which people learn how to create familial stagings and performances that make other people and themselves happy. In ritual action, all involved acquire the practical knowledge that is required for it (Wulf et al. 2001, 2004, 2007, 2010, 2011b).

\section{Gestures}

In the context of rituals, gestures play an important role. Gestures are actions such as the offering of a sacrifice in a sacred ritual in front of a Buddhist family altar. The ringing of a small bell at the beginning of the handing out of presents on Christmas Eve can also be understood as a meaningful gesture in the Christmas ritual. In family rituals, gestures are performative to a great extent; they are mimetically learned. Gestures are movements of the body. They create, represent, and structure the flow of emotions. The significance of a ritual often intensifies in its staging and performance. Gestures make a contribution to creating the social and controlling familial communication and interaction. They make something visible that would not emerge without them. Gestures are spontaneous, ludic and shape transitions. They are intractably linked with language, thought, and imagination. Great importance is attributed to them for the emergence of shared attention and human communication and cooperation (Tomasello, 2009). Gestures can contribute to the production and representation of emotions of well-being and happiness (Wulf; FischerLichte, 2010; Wulf et al., 2011b).

\section{Ethnography of happiness - $A$ German Japanese Study}

The focus of our German-Japanese ethnographic studies lies in the question of the form, that is, the performative and ritual shaping of happiness. Familial happiness is generated, stabilized, and renewed in large part through 
rituals. That is why we also focus on the associated modus operandi of familial happiness. During the respective family celebrations, the questions of what happiness they expect at their celebrations, how the members of the family stage familial happiness, how they create situations of familial happiness through social action, and how they ultimately experience and understand happiness are investigated at the homes of the families. At the same time, which interactions the various family members perform and what happiness effects these have on the social and personal level are worked out.

In contrast to the quantitative or qualitative interview methods, an expansion and shifting of the focus of the methodological spectrum is carried out in order to realize these research perspectives. With the qualitative interviews, which have both an episodic and narrative character, the focus is on content, forms, conditions, and objectives of familial happiness; for this reason, they are primarily carried out as group interviews. Ethnographic data is also supplemented through participatory observation (and observational participation), photography, and videography, as well as through informal conversation with the family members (Bohnsack, 2009). We assume that the complexity of familial happiness, with its traditions, developments, current staging forms, generative perspectives, and symbolic references can only be recorded through a combination of visual, verbal, and textual data.

In order to be able to study the complexity of familial happiness, we have restricted this ethnographic research to the most important family ritual in each case. The importance of rituals for the happiness of children and the family is emphasized not just in self-help parenting books. Certain family rituals, such as eating together in the community of the family, vacations, birthdays, (leisure) activities, and Christmas, are central for familial happiness. In our interpretation, that is why family rituals are used not just to confirm the shared identity and community of the family members, to display and impart values and traditions, to create a common framework of action, or also to develop identities, roles, and abilities - they are used for the performative creation of familial happiness as well (Audehm; Wulf; Zirfas, 2007; Wulf et al., 2011).

\section{Christmas in a Berlin family, New Year in a Japanese family}

In a project established in the "Languages of Emotion" Cluster of Excellence of the Free University of Berlin and in the "Happiness" Cluster

Horizontes Antropológicos, Porto Alegre, ano 23, n. 49, p. 21-59, set./dez. 2017 
of Excellence of Kyoto University, three German-Japanese teams studied the Christmas ritual in three German families and the New Year's ritual in three Japanese families. Without being able to go into the methodological questions interesting for a global cultural studies network research project at this point, some common features could be identified in the shaping of the central family ritual. In my further remarks, I will focus on two families in Berlin-Tegel and Higashimonobeie near Kyoto. The Berlin family consists of the parents and four children, the Japanese family of the grandparents and the two families of their children. The German and the Japanese families belong to the middle class; they observe the celebratory ritual in their own houses; both families have a religious orientation. Both families were selected according to criteria of theoretical sampling and the questions and hypotheses upon which this sampling is based.

\section{Christmas in a Berlin family}

Arrival: As we (Shoko Suzuki and Christoph Wulf) approach the home of the Schultz family in Konrads Höhe in a residential district of Tegel on the afternoon of the 24th of December, it had begun to rain. Our small group consists of three Japanese and one German. We drive through the Tegel Forest, passing by numerous single-family homes, until we arrive at the street on which the family's semi-detached house is located. The family consists of both parents, Mother Frauke (Protestant), Father Ingo (Catholic), and four children (Protestant). We are expected and are cordially greeted by the mother and then by the father. Curious about what is happening, the four children now come out of their rooms on the two floors above. They are introduced to us. When the family asks what we are expecting, we answer that they should pay as little attention to us as possible and that they should celebrate Christmas as always.

In these hours of the year, the familiar Christmas songs change the living room into a sacred space, which is reinforced by the songs that all family members sing together from time to time. The seating area with the Christmas tree and presents underneath is located in a niche across from the table. The Christmas tree is decorated with red baubles, wooden decorations, red ribbons, and an electric string of lights. It is the sacred center of the living room and the family's staging of happiness on Christmas Eve...

Attending a church service: In the early evening, we walk with Mother Frauke and Kevin to the Protestant church that is located just a few minutes

Horizontes Antropológicos, Porto Alegre, ano 23, n. 49, p. 21-59, set./dez. 2017 
away. The other family members have reserved seats for us there. As the bells rings, the pastor approaches the altar. After some brief organ music, he greets the congregation, says a few words about those who are sick and not able to attend, and asks for the Lord's blessing for the holiday congregation, which then sings "Es ist ein Ros entsprungen” ("Lo, How a Rose E'er Blooming”). Then, as is the case every year, the Christmas story according to the apostle Luke is read. The congregation then sings "Vom Himmel hoch, da komm ich her" ("From Heaven Above to Earth I Come”). The sermon follows, which centers on the star that can only be seen with one's heart, a star that shines like God and warms one like his love. This is followed by an interpretation of the gifts brought to Jesus by the Three Kings, in which gold is equated with dignity, honor, and recognition; incense with the soul ascending to God; and myrrh with encouragement and healing. Organ music and other Christmas songs sung by the entire congregation resound...

Back at home again, the handing out of the presents begins. It is introduced by Mother Frauke again reading the Christmas story "Wie Jesus auf die Welt kam" ("How Jesus Came into the World") in the Berlin dialect to the children and husband sitting closely together in front of the Christmas tree. As the story is announced, everyone applauds approvingly. It was apparently part of the family tradition to listen to this "modernization" of the Christmas story. It is the same story told by the apostle Luke, but it comes across so differently through the Berlin dialect that everyone needs to listen carefully to recognize and understand it.

The handing out of presents takes more than two hours. Since each of the six members of the family receives a present from the other family members and the children receive several presents from the parents, many presents are exchanged. The handing out of presents is experienced by everyone as highly intensive and exciting. This time Elias, as the oldest child of the family, is the first to receive a present. It is a DVD of the film "Der Club der toten Dichter" ("Dead Poets Society"). Everyone watches as he unwraps it. Everyone curiously waits to see what sort of present he has received. Comments on the present come from several sides: "You wanted to have that," "Cool," "I'd like to see that film too." The other three children also take the DVD in hand and look at it. The presentation of this present and the comments that accompany this activity make it clear: this DVD is being given not just to Elias, but to the entire family. The attention paid to it makes the present into a part of the 
family community. It belongs to the oldest son, to be sure, but all the others participate in the process of giving and receiving the present. All family members identify with the receiver of the present. Everyone puts his- or herself into his place for a moment and joins him in his happiness. The present is not so much about the material value, but rather the attention and recognition given to the person receiving the present.

Special attention is paid to a present for the mother that the children need to fetch from another room and whose shape suggests a picture. There is great astonishment as the present turns out to be a doormat for the entrance with the inscription "Hotel Mama". The mother is especially happy about this present in particular. She feels that she and her dedication to the family has been validated and recognized. The commentary of all family members is correspondingly extensive, with everyone emphasizing the constant presence of the mother and her care in front of the entire family. Father Ingo encapsulates what they are all feeling: "Mom is happy now."

During the handing out of presents, the family members sit close together in the seating area near the Christmas tree. Their bodies touch each other: tucked-in legs are next to extended arms, hips next to drawn-up knees, heads on the shoulders of the siblings. The family members crowd in close to each other in front of the Christmas tree. Some sit on the couch, others on the floor, pressed onto the legs of their siblings, and still others balance themselves on the backrest of the couch. The intertwined bodies of the family members fill the niche in front of the Christmas tree. A collective body is created whose dynamics emerge from the movements during the handing out of presents. The handing out of presents is largely a physical occurrence. The giving and receiving of presents is accompanied by many gestures and comments. Physical proximity plays an important role. Parents and children touch each other and express their happiness and thanks to each other in this way. Gestures of emotional expression oscillate in particular between Mother Frauke and her children. In gift-giving, a movement to the body to the Other occurs, which leads to sensuous proximity, festive joy, intimacy, and feelings of belonging. During the fumbling and touching, the presents and the other family members are immediately felt. Mother Frauke feels and strokes her presents multiple times, as if she could better sense and incorporate her gifts using her sense of touch. In these gestures of mutual physical gift-giving, the family Schultze creates a special form of a collective family body. 
Family happiness: On the first day of Christmas, we meet again with the family in the morning. Today we want to have a conversation about what the family believes makes up its family happiness. This is to supplement the impressions we gained from Christmas Eve. We want to not just observe how the family stages and performs its happiness on this day, but would like to also find out what the family believes its happiness consists of. We want to understand what aspects are important to them, how they assess them, and how they talk about their happiness.

Not just at Christmas, but also in the day-to-day life of the family, the Schultz parents try to make everything possible for their children that is important for their lives, and they try to make them happy. For this, material conditions that make the fulfillment of their and their children's wishes possible are also important. It is first and foremost the daily care for the children provided by the mother that both parents believe to be important. In order to dedicate herself to taking care of the children, Mother Frauke gave up her work as a physiotherapist - against her convictions at the beginning. This decision, without which the comprehensive care for the children would not have been possible, is strongly supported by Father Ingo, whose job allows him to often work from home. Father Ingo spontaneously mentions that the children receive all-inclusive care in daily life. "There's all-inclusive and XXL allinclusive care."

It is especially important to both parents that their children are served a warm lunch every day and that one of them looks after them. For example, the mother brings each child to the door and says goodbye to him or her individually. She also opens the door for each child when he or she returns from school even if he or she already has a key to the front door. Recently Mother Frauke got up each morning at 4:30 am for several weeks in order to make one of her sons breakfast during his internship, sending him into the day on a full stomach. Children's needs are different at each point in time, something that cannot always be predicted and that also differs from one child to the next. Her children could count themselves lucky that she participates in pretty much everything, according to Mother Frauke. In the last twenty years, the Schultz parents have seen their life-task as dedicating themselves entirely to their children...

I interrupt my ethnographic description here and go to the New Year's celebration of the Japanese family and their staging of family happiness that I participated in with Shoko Suzuki, my colleague from Kyoto University. 


\section{The New Year's celebration in a Japanese family in a village}

The village of Higashimonobe is located north of Lake Biwa, Japan's largest lake. It is a typical region for the cultivation of rice (flat with a great amount of water). The village has a long history and ancient traditions that are closely linked with rice cultivation. For example, the irrigation ditches play a major role. They ensure the order and maintenance of the fields. The village orients itself about the irrigation system. It was originally the case that nearly all families of the village were occupied with rice cultivation, something that is reflected in the closely spaced houses, but today only a few families work in rice cultivation. All families have the special family name of the family patriarch who once settled here in the village with his family.

December 31st is called Omisoka. In former times it was the case that all businesses received new cloths for their house entrances on Omisoka. Each house has a small house shrine; on Omisoka, candles are lit there and the people give thanks that the family was able to prosper over the past year; the family also asks that the next year be prosperous. On December 31st, Soba (long, spaghetti-like noodles made from buckwheat) is eaten in the evening. Soba is a symbol for long life. In the night from December 31st to January 1st, the bells are rung in all temples 108 times at midnight (Joya). This Buddhist ritual is intended to get rid of negative desires. It is normally the case that one is not allowed to sleep during this night. According to the tradition, anyone who does sleep will get more white hairs and facial wrinkles. In former times, the people would also spend the night in the shrine (without sleeping). For this reason a large fire is lit at the shrine.

Joya is a very sacred celebration: it receives the annual god of the year to come. All residents of the village wait for the arrival of the god (which is why they are not permitted to sleep). There are twelve annual gods: mouse, cow, tiger, rabbit, dragon, snake, horse, sheep, monkey, bird (chicken), dog, and wild boar. When the annual god comes, the people - or the Japanese, in any case - are born again.

On January 1st, two representatives of the village council go to the Nogita shrine and prepare the reception of the other village residents. Shortly after sunrise, the other village residents come to the shrine for the New Year's greeting. In former times, everyone wore kimonos on this occasion. 
Today the people no longer wear kimonos, but instead formal wear. For the New Year's greeting, each person brings three rice units wrapped in white paper (for the two shrines and the one temple of the village). The people first go to the shrines, then to the temple. Then the people make a brief visit to their relatives (first and foremost the father of the family and the oldest son) to wish them a happy new year. Then a small snack is eaten for breakfast. Around 7:00 am, a drum is beaten in the temple. It symbolizes the beginning of the temple service (a Buddhist mass in the main hall of the temple) which the village residents attend. The father of the family brings a coin wrapped in white paper, the woman an Isho, a sack with rice. Later the New Year's greeting cards to friends, colleagues, etc., are written - and usually in great numbers.

The house in which we (Shoko Suzuki and Christoph Wulf) spent the turn of the year consists of two rooms that form a large room, next to which there are another two rooms separated from each other. A large kitchen branches off from one of these rooms. There are six more rooms on the second floor. On the front side of the large living room across from the entrance, there is a stately Buddhist family altar on the right, and on the left is the Tokonoma, a pictorial scroll with sacred characters; in front of it is a bouquet of flowers arranged in the Ikebana style. To the left of this, the front side of a Shinto shrine is hanging on the side wall above head height. Sacred vessels are arranged underneath it. Across from the Shinto shrine, photographs of the great- and great-great-grandparents hang on the other side wall next to the Buddhist temple. The Buddhist temple and the Shinto shrine are next to each other and form the sacred center of the house in their mutual entanglement. The separation of the Buddhist and Shinto sanctuaries that was aspired to during the Meji period has not occurred here, or it has been reversed. For the Oda family, the Buddhist temple is of special significance. The family belongs to the Jodo-Shinshu school of Japanese Buddhism, in which the greatgrandfather was a lay priest and to which the family still feels closely linked. The sacred works handed down from the great-grandfather lie in this temple. In the course of the New Year's ceremony, a text is read from one of them in Old Japanese. The temple is decorated today. A special triangular cloth just for the New Year's celebration, fresh flowers, new candles, and later two rice cakes stacked one on top of the other with a mandarin orange refer to the turn of the year and the hopes for a healthy and happy life associated with it. 
An Ootsue, an image of the devil that is common in the Shiga district around Lake Biwa, hangs over the exit of the large living room in the direction of the entry area of the house. It shows a devil in hiking gear with a rolled-up sleeping mat on his back and a rice bowl on his stomach. One of his horns is mutilated and he looks more comical then threatening. This devil has only limited forces of evil at his disposal. At the transition to the room next door used primarily as a play area for the children, an image of Fuji refers to one of the most important sacred places in Japan, where love of nature, religious feelings, and aesthetic feelings overlap.

\section{Visit to the cemetery}

An integral component of the New Year's celebration is a visit to the cemetery, to which we set out for in the late afternoon. The graves of the deceased are at the edge of the village next to a modern highway. For the Japanese, the graves are the gateway to the world of the ancestors. All families in the village have a stone monument in which the remains of the deceased are kept after the body is cremated. As we approached the monument of the Oda family, light snow began to fall.

Grandfather Makato performs the ritual. The flowers on the monument are replaced by new ones. Two candles are lit and placed in wind-protected containers. Incense sticks are lit and placed in the cups provided for this purpose. Water is poured into one of the bowls in front of the candles; the rest of the water is poured over the tip of the monument. Lastly, two small books are produced, from which the grandfather, son, and granddaughter read prayers. For this they kneel in front of the marble monument with their hands folded between a prayer chain. It gradually gets dark, the snowfall becomes heavier, and we drive back to the house.

New Year's meal: The preparation of the New Year's meal is women's work. It is generally the case that the daughter-in-law must learn the customs and ways of the family into which she has married - the way of cutting the vegetables, the cooking, the seasoning of the meal, and the table and plate decoration, for example. The young woman is to be guided by the mother-in-law. As a young daughter-in-law, Grandmother Oda learned this in the exact same way. After the death of her mother-in-law, she slowly began to prepare the food according to her own tastes. Over the course of time, she also took into 
account the wishes of the younger generation and the grandchildren, as well as elements from Western cuisine, in the preparation of the New Year's meal. Today her daughter-in-law helps her in the preparation of the New Year's meal. Like she herself did before, her daughter-in-law learns today to prepare the family meal for the New Year's celebration according to the traditions and customs of the Oda family. In an interview, Grandmother Kayoko explains the significance of the preparation of the traditional family meal.

\section{Family happiness}

A little later, we ask the oldest son Yasuo and his wife to provide us with an interview about family happiness. We ask them about their notions and perceptions of happiness. Yasuo begins to talk to us as if it were a matter of course; later Nanako joins in. Both tell of their notions of happiness and of the threat to their family happiness through the heart defect of their son Kijoichi. For Yasuo and Nanako, the community of the family played a major role. Yasuo tries to be together with the children and to play with them as much as possible. He would like to enable memories for them that are just as nice as the ones from his own childhood. The love of his father Makato is reflected in these memories, and he tries to create similar memories for his children. Passing on parental love to the next generation occurs in a mimetic process in which the foundations are laid for feeling happiness in later life.

New Year's morning: We will see each other again on the morning of New Year's day. As we arrive before 6:00 am at the home of the Oda family, everyone is already awake and dressed for the celebration so that they can festively mark the first day of the new year. We head off with the grandfather and his son in the darkness of the morning to ask for happiness for the new year in a shrine in a temple. It has again begun to snow. While underway, we meet many village residents, almost exclusively men, who like us are walking to the sacred places to ask for blessings for the new year. The women stay at home to prepare the first and especially important meal in the new year. As we arrive at the shrine, two priests are sitting there in their blue garments. The gifts of money prepared yesterday are presented; the bell is rung; it resounds; hands are clapped twice; a small bowl of rice wine is drunk. Then we go to the Buddhist temple. As we meet people underway, we wish them and they wish us a happy new year: Akemaskite omedeto gozaimasu... 


\section{Conditions of family happiness: some considerations}

Without being able to specify what the conditions are for family happiness, three central characteristics can be specified on the basis of our ethnographic material:

- The happiness experienced during the New Year's celebration is a communal happiness that is created by stagings and performances within the family.

- Family happiness is created during the New Year's celebration in and with the aid of performative practices.

- The community of the family differs from other communities through the intensity of the practices that create family happiness.

In the context of our study of the staging and performance of happiness in the Oda family during the New Year's celebration, two family practices are especially important: 1 ) the sacred practices rooted in Shintoism and Buddhism that are constitutive for the happiness of the family studied; 2) the associated practices and symbolic forms of eating and drinking. The sacred practices represent the connection with the cosmic order and the subsumption of the individual life into the succession of ancestors and generations. The practices of eating and drinking are experienced as sensual ones that bring the community together. They contribute to the self-assurance of the family, intensify the communication between the generations and genders, and thus ensure the continued existence of the family.

\section{Iranscultural elements of family happiness}

In the family rituals studied in Germany and Japan, it is the five elements of eating, praying, gift-giving, remembering, and being together that are accorded special significance for the creation of family happiness. Depending on the focus of the description and interpretation, common and different aspects can be differentiated with each of these elements. Each element can be understood as a unitas multiplex whose description and interpretation involves relating the common and the different to each other. It is imperative here to avoid studying just one of the two perspectives without the other. Only with 
an approach that oscillates between the two perspectives can impermissible conceptual and methodological abridgements be avoided. In his thoughts on the "family resemblance" of games, Wittgenstein thoroughly described the problem of working out the unitas multiplex of these elements in family rituals. In the spectrum of family happiness studied, there are many different characteristics, similarities, and differences, so that diversity is created that in principle cannot be comprehended, but within which similarities result that make it possible to perceive and structure this diversity. The basic question of the comparability of cultural phenomena and the possibilities and limits of the comparison arises here, and ensuing from that the question of what people have in common in regard to family happiness (Antweiler 2011).

For both ritual family celebrations, several elements are characteristic, the configuration of which was very different for the two families. Finally, these common features and differences in the shaping of these central family rituals are to be briefly outlined in six points (Wulf et al., 2011a, p. 267-288):

- In both families, the sacred foundation of the family ritual plays an important role. The German family, at the home of which the living room was transformed into a sacred space by the Christmas tree, the many candles, and the familiar Christmas songs, goes on Christmas Eve to the nearby Protestant church to participate in the Christmas service. There they meet other members of the congregation. After the handing out of presents, the Christmas story is read again by the father in two new versions. The fact that one of the two stories is presented in the Berlin dialect causes it to be defamiliarized and transformed into a new story without changing its substance in the process. In the second version, the story is "translated" in a modern newspaper item, showing what great resistance the Christmas happenings would encounter even in our world today.

- In the Japanese family, a visit to the family grave occurs on the last day of the year; the family visits two temples very early on the morning of New Year's Day. On the way there, the residents of the village wish each other a healthy and happy new year. The New Year's ritual is performed in both temples. Then the families go home to attend another ritual that the grandfather performs in front of the Buddhist altar in the living room in the presence of the entire family and to eat the New Year's meal prepared by the women in the night. 
- In the celebration, the communal meal occupies center stage. In the Japanese family, it is eaten while sitting around a table on the floor in front of the Buddhist house temple. On New Year's Day, special dishes are cooked whose symbolic meaning for the new year is spoken about during the meal. The family members sit closely together; they say very little. For the German family, less significance is attributed to the food consumed at the dining table. The mother emphasizes that she not a great "chef" and refuses to make a special effort on this day. The family community is created first and foremost through the conversations at the table, the intensity of which is characteristic of the style of this family.

- The exchange of gifts plays a role in both family rituals. While this is rather marginal in the Japanese family, it plays a central role in the German family. It is not so much its material value as its social significance that puts it at the center of the family ritual. The two-hour-long exchange of gifts takes place in the seating area in front of the Christmas tree. All family members sit there closely pressed together. Each gift is commented upon by all members of the family regarding its benefit for the person receiving it and its social and aesthetic quality.

- Families constitute their feelings of community through narratives in which the members of the family remember events experienced together, bring the respective present into line with the reference frame of the family, and articulate future projections together. Family narrations generate, confirm, and safeguard feelings of belonging.

- During the celebratory ritual, the family members take time for each other, for their togetherness. They enjoy being together and with each other. That is expressed in the German family in the extensive conversations borne by affection. In the Japanese family, it is expressed in the games of the adults with the children, during which the children receive special attention. In the conversations in the German family that we recorded, the children repeatedly express that they would like to later have a family and children, and that they want to pattern their future family life after the model of their family. In the Japanese family, the value of this family ritual that brings together three generations is expressed in the common preparation of the meals by the grandmother, her daughter, and her daughter-in-law, and the high level of appreciation for the meal. 
A clear difference between the German and Japanese families arises from the meaning of the parents and previous generations for the family members. In the German family, the father's parents who live nearby and whom the family thus sees from time to time are visited on the afternoon of the first day of the holiday. Packages with presents are exchanged with the mother's parents, who live quite far away. Telephone calls are placed during the Christmas holiday. In the Japanese family, the family ritual takes place in the house of the grandparents, where three generations participated (four until a few years ago). The family also visits the family grave on the last day of the old year in order to commemorate the ancestors, to thank them, and to ask their blessing for the new year. The grandfather performs a ritual with water, fire, flowers, and the recitation of sacred sayings, in which he also involves the little grandson.

In the conversation with the family members of both families, it became clear what central significance the Christmas and New Year's rituals have for the coherence of the family and the happiness of its members. In both families, narrative recourse to previous Christmas and New Year's celebrations and narrative projections to future celebrations embed the present of the family celebration in the history and expected future of the family. This creates an emotional intensity and a feeling of shared identity that the family members experience as family happiness. Durkheim (1994) correctly pointed out how important the sacred character constituted in such rituals is for the family for it to be able to realize its societal and social function. Values, standards, and rules that are binding for the family are demonstrated in the staging of such rituals with their performative practices and their accompanying narrations that generate their meaning. They are created in these processes, incorporated in the behavior of the family members, and confirmed again and again through repetition. These values, standards, and rules, as well as the feelings intertwined with them, do not enter the consciousness of the family members as abstract values. Rather, they are integrated into staged actions, conversations, and behaviors of which one only becomes conscious in case of conflicts or upon targeted questioning of the reasons behind them. They are part of an action knowledge that gives the family members the ability to take the correct action in accordance with the situation. 


\section{References}

ARIÈS, P.; DUBY, G. (Ed.). Histoire de la vie privée. Paris: Seuil, 1985. 5 v.

AUDEHM, K.; WULF, C.; ZIRFAS, J. Rituale. In: ECARIUS, J. (Hrsg.). Handbuch Familie. Wiesbaden: Springer VS, 2007. p. 424-440.

BAITELLO, N.; WULF, C. (Ed.). Emoção e imaginação. São Paulo: Estação das Letras e Cores, 2014.

BAUMANN, M.; HAURI, R. (Hrsg.). Weihnachten: Familienritual zwischen Tradition und Kreativität. Stuttgart: Kohlhammer, 2008.

BOHNSACK, R. Qualitative Bild- und Videointerpretation: die dokumentarische Methode. Opladen: Barbara Budrich, 2009.

BRAUDEL, F. La Méditerranée et le monde méditerranéen à l'époque de Philippe II. Paris: Armand Colin, 1949.

BURKE, P. The French Historical Revolution: the Annales School, 1929-89. Stanford: Stanford University Press, 1991.

DINZELBACHER, P. (Hrsg.). Europäische Mentalitätsgeschichte: Hauptthemen in Einzeldarstellungen. Stuttgart: Kroener, 1993.

DURKHEIM, E. Die elementaren Formen des religiösen Lebens. Frankfurt: Suhrkamp, 1994.

EKMAN, P. E.; SORENSON, R.; ELLSWORTH, P. Emotions in the human face. New York: Pergamon, 1982.

EVANS-PRITCHARD, E. E. A history of anthropological thought. London: Faber and Faber, 1981.

FREVERT, U.; WULF, C. (Hrsg.). Die Bildung der Gefühle. Sonderheft der Zeitschrift für Erziehungswissenschaft, Hamburg, n. 16, 2012.

GEBAUER, G.; WULF, C. Mimesis: culture, art, society. Berkeley: California University Press, 1995. 
GEBAUER, G.; WULF, C. Spiel, Ritual, Geste: mimetisches Handeln in der sozialen Welt. Reinbek: Rowohlt, 1998.

GEBAUER, G.; WULF, C. Mimese na cultura. São Paulo: Annablume, 2004.

GEHLEN, A. Man: his nature and place in the world. New York: Columbia University Press, 1988.

GIL, I. C.; WULF, C. (Ed.). Hazardous future: disaster, representation and the assessment of risk. Berlin: De Gruyter, 2015.

GINZBURG, C. The cheese and the worms: the cosmos of a sixteenth-century miller. New York: Penguin Books, 1982.

GLASER, B. G.; STRAUSS, A. Grounded Theory: Strategien qualitativer Forschung. Bern: Huber, 1998.

GRECO, M.; STENNER, P. (Ed.). Emotions: a social science reader. London: Routledge, 2008.

HAHN, A. Körper und Gedächtnis. Wiesbaden: Springer VS, 2010a.

HAHN, A. Emotion und Gedächtnis. Paragrana, Berlin, v. 19, n. 1, p. 15-31, 2010b.

HARDING, J.; PRIBRAM, E. D. (Ed.). Emotions: a cultural studies reader. London: Routledge, 2009.

HARRIS, M. The rise of anthropological theory: a history of theories of cultures. rev. ed. Walnut Creek: AltaMira Press, 2001.

HORN, C. Antike Lebenskunst: Glück und Moral von Sokrates bis zu den Neuplatonikern. München: Beck, 1998.

HOYER, T. (Hrsg.). Vom Glück und glücklichen Leben: sozial- und geisteswissenschaftliche Zugänge. Göttingen: Vandenhoeck \& Ruprecht, 2007.

KRAUS, A. et al. (Hrsg.). Handbuch schweigendes Wissen: Erziehung, Bildung, Sozialisation und Lernen. Weinheim: Beltz Juventa, 2017. 
LADURIE, E. L. R. Montaillou: Cathars and Catholics in a French village, 1294-1324. London: Scolar Press, 1978.

LAUSTER, J. Gott und das Glück: das Schicksal des guten Lebens im Christentum. Darmstadt: Wissenschaftliche Buchgesellschaft, 2004.

LE BRETON, D. Les passions ordinaires: anthropologie des émotions. Paris: Armand Colin, 1998.

LE GOFF, J. (Ed.). The medieval world. London: Collins Brown, 1990.

LÉVI-STRAUSS, C. Tristes tropiques. New York: Penguin Books, 1992.

LÉVI-STRAUSS, C. Structural anthropology. New York: Basic Books, 1999.

MALINOWSKI, B. K. Argonauts of the Western Pacific. London: Routledge, 1992.

MEAD, M. Sex and temperament in three primitive societies. New York: Morrow Quill Paperbacks, 1980.

MEAD, M. Growing up in New Guinea: a comparative study of primitive education. New York: Harper Collins, 2001.

MEDICK, H.; SABEAN, D. W. (Ed.). Interest and emotion: essays on the study of family and kinship. New York: Cambridge University Press, 1984.

MICHAELS, A. (Hrsg.). Die neue Kraft der Rituale. Heidelberg: Winter, 2007.

MICHAELS, A.; WULF, C. (Ed.). Images of the body in India. London: Routledge, 2011.

MICHAELS, A.; WULF, C. (Ed.). Emotions in rituals and performances. London: Routledge, 2012.

MICHAELS, A.; WULF, C. (Ed.). Exploring the senses: emotions, performativity, and ritual. London: Routledge, 2014.

MORIN, E. Das Rätsel des Humanen. München: Piper, 1973. 
MORIN, E.; WULF, C. Planeta: a aventura desconhecida. São Paulo: Editora Unesp, 2003.

MORGENTHALER, C.; HAURI, R. (Hrsg.). Rituale im Familienleben: Inhalte, Formen und Funktionen im Verhältnis der Generationen. Weinheim: Juventa, 2010.

PARAGRANA. Berlin, v. 19, n. 1, 2010a. Emotion, Bewegung, Körper. Gunter Gebauer und Christoph Wulf (Hrsg.).

PARAGRANA. Berlin, v. 19, n. 2, 2010b. Kontaktzonen. Christoph Wulf (Hrsg.).

PARAGRANA. Berlin, v. 20, n. 2, 2011. Emotionen in einer transkulturellen Welt. Christoph Wulf, Jacques Poulain und Fathi Triki (Hrsg.).

PLESSNER, H. Laughing and crying: a study of the limits of human behavior. Evanston: Northwestern University Press, 1970.

SAHLINS, M. Culture and practical reason. Chicago: University of Chicago Press, 1976.

SENECA. Epistulae morales ad Lucilium. Düsseldorf: Artemis und Winkler, 2007.

SUZUKI, S.; WULF, C. (Ed.). Mimesis, poiesis, performativity in education. Muenster: Waxmann, 2007.

TOMASELLO, M. Die Ursprünge der menschlichen Kommunikation. Frankfurt: Suhrkamp, 2009.

UNESCO. Convention for the safeguarding of the intangible cultural heritage. Paris, 2003.

UNESCO. Convention on the protection and promotion of the diversity of cultural expression. Paris, 2005.

WULF, C. (Ed.). Traité d'anthropologie historique: philosophies, histoires, cultures. Paris: L’Harmattan, 2002. 
WULF, C. Zur Genese des Sozialen: Mimesis, Performativität, Ritual. Bielefeld: Transcript, 2005a.

WULF, C. Crucial points in the transmission and learning of intangible heritage. In: GLOBALIZATION and Intangible Cultural Heritage. Paris: UNESCO, 2005b. p. 84-95.

WULF, C. Anthropologie kultureller Vielfalt. Bielefeld: Transcript, 2006.

WULF, C. (Hrsg.). Der Mensch und seine Kultur: hundert Beiträge zu Problemen des menschlichen Lebens in Vergangenheit, Gegenwart und Zukunft. Köln: Anaconda, 2010.

WULF, C. Anthropology: a continental perspective. Chicago: University of Chicago Press, 2013a.

WULF, C. Das Rätsel des Humanen. München: Wilhelm Fink, 2013b.

WULF, C. (Ed.). Exploring alterity in a globalized world. London: Routledge, 2016.

WULF, C. Antropologia do homem global. São Paulo: Annablume, 2017.

WULF, C.; FISCHER-LICHTE, E. (Hrsg.). Gesten: Inszenierung, Aufführung, Praxis. München: Wilhelm Fink, 2010.

WULF, C.; GÖHLICH, M.; ZIRFAS, J.(Hrsg.). Grundlagen des Performativen: eine Einführung in die Zusammenhänge von Sprache, Macht und Handeln. Weinheim: Beltz Juventa, 2001.

WULF, C.; KAMPER, D. (Hrsg.). Logik und Leidenschaft: erträge historischer Anthropologie. Berlin: Reimer, 2002.

WULF, C.; ZIRFAS, J. Die Kultur des Rituals: Inszenierungen, Praktiken, Symbole. München: Wilhelm Fink, 2004.

WULF, C.; ZIRFAS, J. (Hrsg.). Pädagogik des Performativen: Theorien, Methoden, Perspektiven. Weinheim: Beltz, 2007.

WULF, C.; ZIRFAS, J. (Hrsg.). Handbuch pädagogische Anthropologie. Wiesbaden: Springer VS, 2014. 
WULF, C. et al. Das Soziale als Ritual: Zur performativen Bildung von Gemeinschaften. Opladen: Leske und Budrich, 2001.

WULF, C. et al. Bildung im Ritual: Schule, Familie, Jugend, Medien. Wiesbaden: Verlag für Sozialwissenschaften, 2004.

WULF, C. et al. Lernkulturen im Umbruch: Rituelle Praktiken in Schule, Medien, Familie und Jugend. Wiesbaden: Verlag für Sozialwissenschaften, 2007.

WULF, C. et al. Ritual and identity: the staging and performing of rituals in the lives of young people. London: Tufnell, 2010.

WULF, C. et al. Das Glück der Familie: ethnographische Studien in Deutschland und Japan. Wiesbaden: Springer VS, 2011a.

WULF, C. et al. Die Geste in Erziehung, Bildung und Sozialisation: ethnographische Fallstudien. Wiesbaden: Verlag für Sozialwissenschaften, 2011b.

WULFF, H. (Ed.). The emotions: a cultural reader. New York: Berg, 2007. 